\title{
Confirmation of Transgenic Robusta Coffee (Coffea canephora) Transformed by Chitinase-encoding Gene and Its Propagation Through Somatic Embryogenesis
}

\author{
Konfirmasi Kopi Robusta (Coffea canephora) Transgenik Hasil \\ Transformasi dengan Gen Chitinase dan Perbanyakannya \\ Melalui Embriogenesis Somatik
}

Priyono $^{1)}$, A. Budiani ${ }^{2)}$, Surip Mawardi ${ }^{1)}$ and Siswanto ${ }^{2)}$

\begin{abstract}
Summary
Genetic engineering of Robusta coffee resistant to fungal diseases might be done by introducing a chitinase-encoding gene into genome of this plant. This research was aimed to confirm transgenic plant of BP 308 clone Robusta coffee transformed by chi gene and to evaluate its ability for the somatic embryogenesis. Confirmation of transgenic was carried out by analysis the presence of NPTII gene as a selectable marker for Canamysin resistant using PCR technique. The somatic embryo initiation and reproduction were evaluated in 11 plant accessions. Three kinds of sucrose concentration, 20\%, 30\% and 40\% were applied in initiation stage of somatic embryo germination. The suitability of 4 medium, namely M1 (without addition by liquid medium), M2 (addition by liquid medium contained $0.25 \mathrm{mg} / 1$ kinetin), M3 (addition by liquid medium contained $0.25 \mathrm{mg} / \mathrm{l} \mathrm{IAA}$ ) and M4 (addition by liquid medium contained $0.25 \mathrm{mg} / \mathrm{l}$ $\mathrm{GA}_{3}$ ) was evaluated for somatic embryo maturation. The result showed that 8 out of 10 plant accessions tested were transgenic and they could be propagated through somatic embryogenesis. The ability of transgenic plant for somatic embryo initiation, reproduction and regeneration were similar with that of nontransgenic one. Germination of somatic embryo could be improved by using $40 \%$ sucrose. Maturation of somatic embryo could be improved by addition of fresh liquid medium on the ancient gelled medium that used for somatic embryos reproduction. The best result was obtained on addition of fresh medium contained $0.25 \mathrm{mg} / 1 \mathrm{GA}_{3}$ in which $65 \%$ of the somatic embryos developed to pre-germinate somatic embryo.
\end{abstract}

Key words: Coffea canephora, transgenic plant, somatic embryogenesis.

1) Senior Researcher (Ahli Peneliti); Indonesian Coffee and Cocoa Research Institute, Jl. P.B. Sudirman 90, Jember 68118, Indonesia.

2) Senior Researcher (Ahli Peneliti); Biotechnology Research Institute for Estate Crops, Jl. Taman Kencana No. 1, Bogor 16151 , Indonesia. 


\section{Ringkasan}

Rekayasa genetika kopi Robusta untuk ketahanan terhadap fungi dapat dilakukan dengan memasukkan gen kitinase pada genome tanaman tersebut. Penelitian ini ditujukan untuk mengkonfirmasi tanaman transgenik kopi Robusta klon BP 308 hasil transformasi menggunakan konstruk gen chi dan mengevaluasi kemampuan embriogenesis somatiknya. Konfirmasi transgenik dilakukan dengan menganalisis adanya fragmen DNA gen NPTII sebagai penanda seleksi terhadap kanamisin dengan teknik PCR. Inisiasi dan reproduksi embrio somatik terdiri atas 11 perlakuan, yaitu 11 aksesi tanaman. Pengecambahan embrio somatik terdiri atas 33 perlakuan, yaitu kombinasi 11 aksesi tanaman dengan 3 konsentrasi sukrosa, yaitu 20\%, 30\% dan 40\%. Pendewasaan embrio somatik terdiri atas 44 perlakuan, yaitu kombinasi 11 aksesi tanaman dengan 4 jenis media cair yang ditambahkan pada embrio somatik tahap reproduksi embrio somatik, yaitu M1 (tanpa penambahan medium cair), M2 (medium cair diperkaya 0,25 mg/l kinetin), M3 (medium cair diperkaya 0,25 mg/l IAA) dan M4 (medium cair diperkaya 0,25 mg/l GA3). Hasil penelitian menunjukkan bahwa 8 dari 10 tanaman hasil transformasi terbukti sebagai tanaman transgenik. Kemampuan embriogenesis somatik tanaman transgenik tidak berbeda dengan tanaman non transgenik. Pengecambahan embrio somatik semua aksesi tanaman yang diuji dapat ditingkatkan dengan menggunakan media perakaran yang diperkaya dengan $40 \%$ sukrosa. Pendewasaan embrio somatik dapat diperbaiki dengan menambahkan media cair yang diperkaya dengan 0,25 mg/l GA. Dengan penambahan media ini $65 \%$ embrio somatik dapat mencapai fase prakecambah.

\section{INTRODUCTION}

Coffee is a very important crop in Indonesia. One of the problems associated with the plantation of Robusta coffee is the susceptibility of this crop to fungal diseases caused by Fomes lamoensis and Rigidophorus lignosus. Unfortunately, conventional breeding of this crop for introducing new agronomical traits, such as disease resistant is considered difficult because of the long duration of cultivation before seeds are set. In the case where coffee does not have natural resistance for pest and disease, it would be very useful to have a system for the genetic transformation permitting the incorporation necessary to have an in vitro culture system, which permits a high frequency of regeneration (Da Silva \& Yuffa, 2003).
Based on this reason, one of the most important aspects strategic is by providing superior planting materials, which are having a good quality (physically and genetically) and propagated by appropriated technology.

Genetic engineering of coffee resistant to fungal diseases can be done by introducing chitinase-encoding gene into genome of this plant. Chitinases are one class of pathogenesis-related proteins, which have been implicated in plant defence against fungal infection by lysing the hyphal tips (Budiani et al., 2001). This enzyme catalyses the hydrolysis of $\beta$-1,4-linkage of $\mathrm{N}$-acetylglucosamine polymer of chitin, a major component of fungal cell walls. Introduction of this gene into cells of Robusta coffee fol- 
lowed by plantlet regeneration in the selection media would results in transgenic plant of Robusta coffee resistant to $F$. lamoensis and $R$. lignosus.

Insertion of chitinases-encoding gene into plant genome has been reported for rice (Lin et al., 1995), cucumber (Raharjo et al., 1996), tobacco (Terakawa et al., 1997) and Arabica coffee (Budiani et al., 2001). Highlevel expression of chitinase in transgenic plant can enhance resistance to a variety of fungal pathogens (Broglie et al., 1991; Lin et al., 1995). Unfortunately, by the number of transgenic plant produced is considered to be limited. On the other hand, level of somatic embryogenesis of transgenic plant is also lower compared to that of the nontransgenic one, probably caused by the use of antibiotic in the media and insertion of foreign genes. This phenomenon has been reported on Robusta coffee (Priyono et al., 2001). Due to this problem, the large-scale field test of the transgenic plant takes long time. This paper reports a research work on somatic embryogenesis of transgenic Robusta coffee derived from transformed somatic embryos using chitinase-encoding genes.

\section{MATERIALS AND METHODS}

\section{Plant Materials}

The Robusta coffee (Coffea canephora Pierre) clone used in this research was BP 308 that resistant to nematode parasite. Two different explants were used for somatic embryogenesis evaluation, namely transgenic and non-transgenic plants (Table 1). The transgenic plants were produced by direct somatic embryogenesis from pre-embryonic of somatic embryos after transformation using chitinase gene (chi). Transformation was mediated by Agrobacterium tumefaciens LBA4404 strain carrying pCAMBIA2301-chi (Priyono et al., 2001), and the chi gene was obtained from rice.

Table 1. Plant accessions used as explant on in vitro culture of transgenic plant

Tabel 1. Aksesi tanaman yang digunakan sebagai eksplan pada kultur in vitro tanaman transgenik

\begin{tabular}{cl}
\hline $\begin{array}{c}\text { Plant accession } \\
\text { Aksesi tanaman }\end{array}$ & $\begin{array}{c}\text { Remarks } \\
\text { Keterangan }\end{array}$ \\
\hline N & Plant derived from non transformed explant (tanaman asal eksplan yang tidak ditransformasi) \\
T-1 & Plant derived from transformed explant (tanaman asal eksplan yang ditransformasi) \\
T-2 & Plant derived from transformed explant (tanaman asal eksplan yang ditransformasi) \\
T-3 & Plant derived from transformed explant (tanaman asal eksplan yang ditransformasi) \\
T-4 & Plant derived from transformed explant (tanaman asal eksplan yang ditransformasi) \\
T-5 & Plant derived from transformed explant (tanaman asal eksplan yang ditransformasi) \\
T-6 & Plant derived from transformed explant (tanaman asal eksplan yang ditransformasi) \\
T-7 & Plant derived from transformed explant (tanaman asal eksplan yang ditransformasi) \\
T-8 & Plant derived from transformed explant (tanaman asal eksplan yang ditransformasi) \\
T-9 & Plant derived from transformed explant (tanaman asal eksplan yang ditransformasi) \\
T-10 & Plant derived from transformed explant (tanaman asal eksplan yang ditransformasi) \\
\hline
\end{tabular}

Notes (catatan) : T1-T10 were code of accessions from transformed explant (T1-T10 adalah kode aksesi tanaman asal eksplan yang ditransformasi). 


\section{Transgenic Confirmation of The Transformed Robusta Coffee}

PCR analysis using specific oligonucleotide primers for amplifying conserved region of NPTII gene was conducted for confirmation of regenerated Robusta coffee as transgenic plants. The nucleotide sequences of the primers were NPTF: 5'-GCATA CGCTTGATCCGGCTACC-3 and NPTR: 5'-TGATATTCGGCAAG CAGGCAT-3'. These primers amplified NPTII DNA fragment of about $650 \mathrm{bp}$. DNA amplification was carried out using Gene Amp PCR System 2400, programmed for 5 minutes denaturation at $94^{\circ} \mathrm{C}$ followed by 35 cycles; each cycles consist of 45 seconds for denaturation at $94^{\circ} \mathrm{C}, 45$ seconds for primer annealing at $55^{\circ} \mathrm{C}$ and 2 minutes for primer extension at $72^{\circ} \mathrm{C}$. The last cycle was followed by 7 minutes incubation at $72^{\circ} \mathrm{C}$. Amplification product was verified on agarose gel electrophoresis.

\section{Preparation of Explant}

Young leaves were washed in tap water, followed by 1 hour immersion in $1 \mathrm{~g} /$ 1 benlate solution, and then transferred into solution containing 5\% sodium hypochlorite for 30 minutes. After three rinses in sterile distilled water, the leaves were cut and pre-cultured on MS basal media for screening from contamination. After 5-7 days cultured on MS media without plant growth regulator, the leaf explants, which were free from contamination, were used for somatic embryogenesis induction.

\section{Initiation and Reproduction of Somatic Embryo}

This experiment was divided into two sub-experiments, i.e. somatic embryo initiation and embryo induction. Each of subexperiment was arranged by Completely Randomized Design (CRD) with 4 replications. The research consists of 11 treatments of plant accessions as descripted in Table 1. Explants used for somatic embryo initiation is young leaves. In the other side, explants used for somatic embryo reproduction is somatic embryos derived from somatic embryo initiation stage. For inducing somatic embryogenesis, medium consists of basal media $1 / 4$ strength macro salts and $1 / 2$ strength micro salts of MS medium, organic constituents of B5 medium and 30 $\mathrm{g} / 1$ sucrose was used. This medium was supplemented with $0.5 \mathrm{mg} / 1 \mathrm{IAA}, 5 \mathrm{mg} / 1$ BAP and $30 \mu \mathrm{M} \mathrm{AgNO}_{3}$.

\section{Germination of Somatic Embryo}

The experiment in this stage was arranged by factorial design based on Completely Randomized Design (CRD), with 3 replications. The $1^{\text {st }}$ factor was sucrose concentration, which consists of 3 levels, i.e. $20 \%, 30 \%$ and $40 \%$. The $2^{\text {nd }}$ factor was plant accession, which consists of 11 levels plant accessions as presented in Table 1 .

\section{Maturation of Somatic Embryo}

A Completely Randomized Design (CRD) with 3 replications arranged by fac- 
torial design was used in this experiment. The $1^{\text {st }}$ factor was medium which consist of 4 levels, i.e. M1 (gelled somatic embryo reproduction medium without addition of liquid medium on 8 weeks culture old), M2 (gelled somatic embryo reproduction medium with addition of fresh liquid medium contained $0.25 \mathrm{mg} / 1$ kinetin on 8 weeks culture old), M3 (gelled somatic embryo reproduction medium with addition of fresh liquid medium contained $0.25 \mathrm{mg} / \mathrm{l} \mathrm{IAA}$ on 8 weeks culture old) and M4 (gelled somatic embryo reproduction medium with addition of fresh liquid medium contained $0.25 \mathrm{mg} /$ $1 \mathrm{GA}_{3}$ on 8 weeks culture old). The $2^{\text {nd }}$ factor was plant accession, which consists of 11 levels (Table 1).

\section{Culture Maintenance, Observed Traits and Data Analysis}

All cultures were maintained at temperature of $25-28^{\circ} \mathrm{C}$ and $16 \mathrm{~h}$ photoperiod. The light intensity (cool white fluorescent lamps; $40 \mathrm{~cm}$ above vials), which supported maximum growth at the various stages of development, maintained at 2000 lux.

Trait observed at both somatic embryo induction and somatic embryo reproduction covered somatic embryogenesis frequency, number of somatic embryo, size of somatic embryo, and phase of somatic embryo. Trait observed at somatic embryo maturation covered, number of somatic embryo, size of somatic embryo and phase of somatic embryo. Trait observed at plantlet regeneration covered germinated embryos, rootedshoots, number of root per shoot, root length and shoot high. Somatic embryogenesis fre- quency was observed at 4-12 weeks after culture. The others traits were calculated at 12 weeks after culture. All data were analysed by using LSD Test.

\section{RESULTS AND DISCUSSION}

\section{Transgenic Confirmation of The Transformed Robusta Coffee}

The result of PCR analysis confirmed that 8 plants (lanes 1, 2, 3, 4, 7, 8, 9, 10) out of 10 plants tested were transgenic (Figure 1). The NPTII gene was chosen in spite of chi gene for confirmation of transgenic, since amplifying DNA of the chi gene would be bias with that of endogenous chi. Further analysis needed would be expression analysis of the chitinase by means of Northern hybridization or reverse transcriptase PCR (RT-PCR).

This result showed that $80 \%$ of plants derived from transformed explant was transgenic plant. The previous report (Priyono et al., 2001) showed that depending on explant types, 10-62\% of explant cultured on Agrobacterium tumefaciens mediated transformation medium was transformed explant. It mean that the frequency of transgenic plant of Robusta coffee by using the procedure reported by Priyono et al. (2001) were 8-50\%, depending on explant type and concentration of $\mathrm{AgNO}_{3}$. The lower of frequency of transgenic plant, namely $5 \%$ was reported by Leroy et al. (1997) on gene transformation by using of Agrobacterium sp. on somatic embryos of Robusta coffee. Wirawan et al. (1999) also reported that 


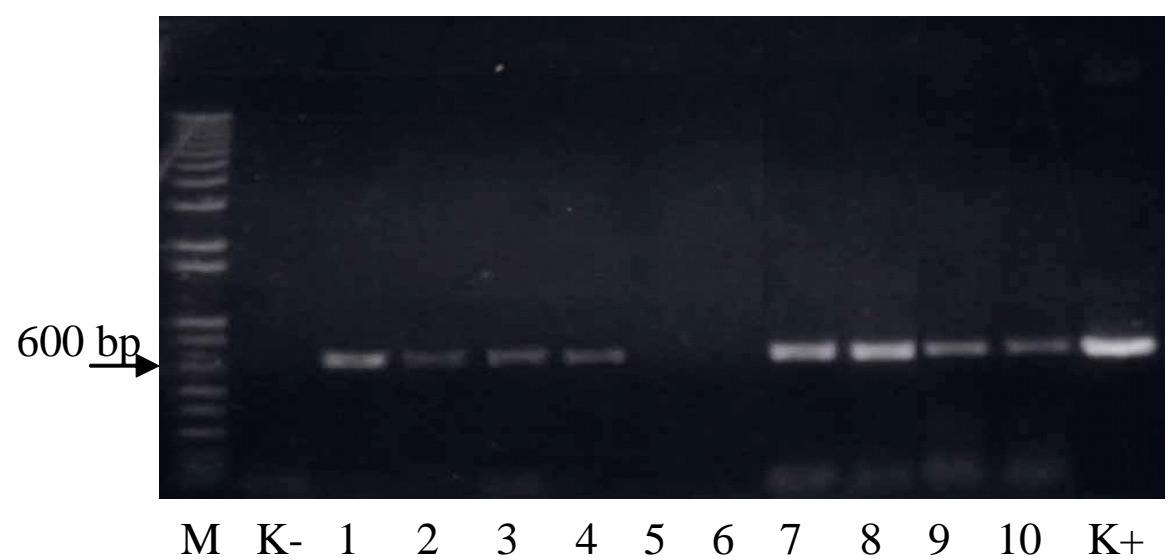

Figure 1. Amplification product using NPTII sprcific primers of genomic DNA from 10 Robusta coffee plants transformed with $c h i$ gene. Notes: $\mathrm{K}_{-}=$negative control of untransformed plant; lane $1-10=$ transformed plants of $\mathrm{T} 1-\mathrm{T} 10$ respectively; $\mathrm{K}+=$ positive control of pCAMBIA2301-chi.

Gambar 1. Hasil amplifikasi menggunakan primer spesifik NPTII dari DNA genomik 10 tanaman kopi Robusta hasil transformasi menggunakan gen chi. Catatan: $K-=K o n t r o l ~ n e g a t i f ~ t a n a m a n$ kopi Robusta yang tidak ditransformasi; lajur 1-10= tanaman kopi Robusta hasil transformasi, berturut-turut T1-T10; $\mathrm{K}+=$ control positif plasmid pCAMBIA2301-chi.

$10 \%$ of transformed explant on tips shoots culture of Citrus showed the clear transgenic plant after confirmed by the GUS expression.

\section{Initiation, Reproduction and Germi- nation of Somatic Embryos}

Somatic embryogenesis cauld be obtained both from transgenic and nontransgenic plants (Figure 2). The abilities of somatic embryogenesis of both plants were presented in Figure 3 and Table 2. Figure 3 showed that the precocity of somatic embryo formation in somatic embryo initiation stage of transgenic plant was not different with non-transgenic one. Furthermore, the frequency of somatic embryogen- esis in same stage of transgenic plant was not significantly different with non-transgenic one. The same result also obtained from somatic embryo reproduction stage, however compared with initiation stages for all of the plants tested with in stage of somatic embryo reproduction showed that the precocity of somatic embryogenesis of reproduction stage was grew faster than on initiation one. Table 3 showed that both the number and size of somatic embryos derived from transgenic plant was not significantly different also with non-transgenic one. Its means that the performance of somatic embryos derived from transgenic plant was similar with non-transgenic one.

The development of somatic embryos derived from transgenic plant was not dif- 
fering to that of non-transgenic one. The phase of somatic embryos derived both from transgenic plant and non-transgenic one was dominated by cotyledon phase. As like the performance of somatic embryos, there was no significantly differences of somatic embryos development between all plants in stage of somatic embryo reproduction. This similar evidence also showed among transgenic plant both on initiation stage and reproduction one.

Germination of somatic embryos derived from transgenic plantlet after two months cultured in the media with different concentration of sucrose was presented in Table 4. Concentrations of sucrose significantly affected the percentage of germinated embryos, fresh weight of plantlet, dry matter of plantlet, number of root per shoot, length of root and shoot high. In general, the higher sucrose concentration used in the regeneration media improved the somatic embryos germination. These result showed that sucrose was an effective carbon source and it indicated that sucrose at concentration of $40 \%$ effectively improved the development of somatic embryos. The similar result had reported by Etienne-Barry et al. (1999) that exposing somatic embryos to high concentration of sucrose in the germination medium 2 weeks before sowing resulted in strong positive effect on their conversion into plant and on the subsequent growth of the plants. The influence of sucrose also obtained in alfafa (Lai \& Mc Kersie, 1995) which showed that an immersion in a solution of sucrose and mineral salts prior to germination that greatly enhanced the conversion into plants and the vigor of the somatic embryos. These results also agreed with Roberts et al. (1994) that Chrysanthemum plantlet grown on Sorbitol as a carbon sources had a well-developed rooting system and less glassy succulence. Takazama \& Kozai (1992) also showed that the combination of culture vessels with a large number of air exchange per hour and Sorbitol, saturated with liquid medium, also promoted the growth of carnation plantlet in vitro. The different result reported by Nguyen et al. (1999) which showed that the greatest root growth and no hyperhydricity during the development of coffee plantlet was obtained when somatic embryos cultured on florialite soaked in sugar-free medium but cultured under condition of large number of air exchanges.

Similar with somatic embryos induction and reproduction stage, in the somatic embryo germination stage showed no significantl effect between non-transgenic plant with transgenic one and among transgenic ones. Somatic embryos derived from non-transgenic plant and somatic embryos derived from transgenic plant of germination similar both on percentage and performance (Table 4). It means that the 8 of transgenic plant still have the same of basic character, especially to somatic embryogenesis abilities and were not different with non-transgenic one. The previous report (Priyono et al., 2000) showed that the abilities of somatic embryogenesis abilities of 6 clones of Robusta coffee tested were significantly different. These result agreed with Priyono (2004) which showed these evidences also obtained from several species of coffee cultured in vitro. 
There were efficient regeneration systems for coffee through somatic embryogenesis from several tissues (Zamarripa,
1991, Hatanaka et al. (1991), and Priyono et al. (2000). Furthermore, some reports about production of transgenic plant in cof-
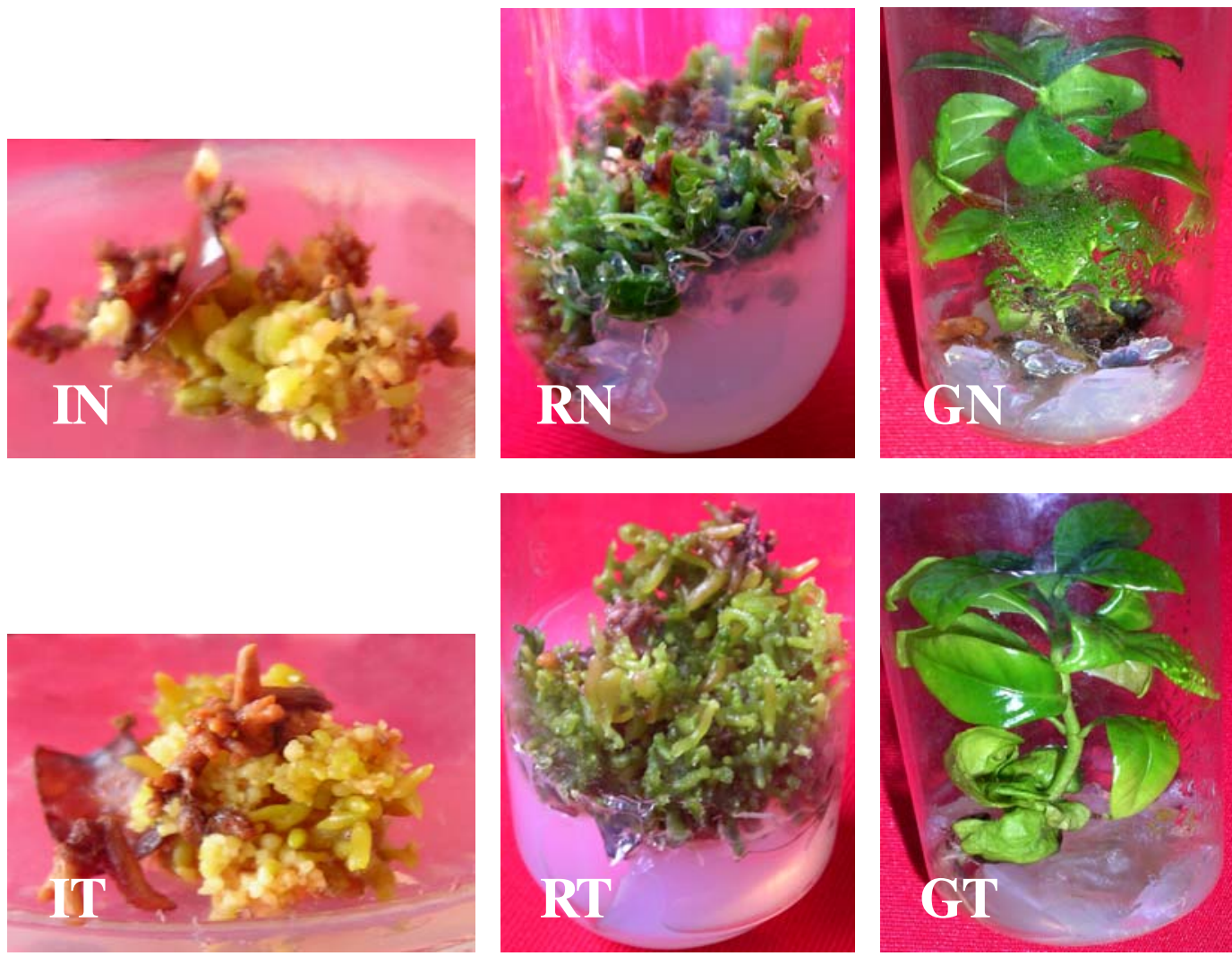

Figure 2. Somatic embryos produced from in vitro culture of $C$. canephora. Notes: IN = somatic embryos of non-transgenic plant produced from somatic embryo initiation stage. $\mathrm{IT}=$ somatic embryos of transgenic plant produced from somatic embryo initiation stage. $\mathrm{RN}=$ somatic embryos of non-transgenic plant produced from somatic embryo reproduction stage. RT= somatic embryos of transgenic plant produced from somatic embryo reproduction stage. $\mathrm{GN}=$ plantlet of non-transgenic plant produced from somatic embryo germination stage $\mathrm{GT}=$ plantlet of transgenic plant produced from somatic embryo germination stage.

Gambar 2. Embrio somatik yang dihasilkan pada kultur in vitro kopi Robusta. Catatan: IN= embrio somatik pada tanaman non transgenik pada tahap inisiasi embrio somatik. IT = embrio somatik pada tanaman transgenik pada tahap inisiasi embrio somatik. RN: embrio somatik tanaman non transgenik pada tahap reproduksi embrio somatik. $R T$ : embrio somatik tanaman transgenik pada tahap reproduksi embrio somatik. GN: plantlet tanaman non transgenik pada tahap pengecambahan embrio somatik. GT: plantlet tanaman transgenik pada tahap pengecambahan embrio somatik. 
fee were reported. Spiral et al. (1993) and Siswanto et al. (2003) transformed C. canephora with Agrobacterium tumefaciens. Barton et al. (1991) transformed C. arabica with Agrobacterium tumefaciens. Leroy et al. (2000) obtained coffee plant of $C$. arabica and $C$. canephora resistant to leaf miner also using the vector Agrobacterium tumefaciens. Van Boxtel et al. (1995) transformed different coffee genotypes by bombardment and then Da Silva \& Yuffa (2003) obtained the transgenic plant of C. arabica by electroporation. However, the report of somatic embryogenesis in transgenic plant of these crops was not yet re- ported. These present studies showed that the abilities of somatic embryogenesis of transgenic plant was similar with nontransgenic one.

An interesting point in the present result was that there was a significantly differences on somatic embryogenesis abilities between transgenic plant with non-transgenic plant, the same evidences was also showed among transgenic one. Silva \& Yuffa (2003) said that to establish a genetic transformation system it was necessary to have was in vitro culture system, which permits a high frequency of regeneration. Furthermore it

Table 2. Number and size of somatic embryo on somatic embryo initiation and reproduction stage of in vitro culture of transgenic plants of Robusta coffee

Tabel 2. Jumlah dan ukuran embrio somatik pada tahap inisiasi dan reproduksi embrio somatik beberapa aksesi tanaman transgenik kopi Robusta

\begin{tabular}{|c|c|c|c|c|}
\hline \multirow{2}{*}{$\begin{array}{l}\text { Plant accession } \\
\text { Aksesi tanaman }\end{array}$} & \multicolumn{2}{|c|}{$\begin{array}{l}\text { Number of somatic embryos } \\
\text { Jumlah embrio somatik }\end{array}$} & \multicolumn{2}{|c|}{$\begin{array}{c}\text { Size of somatic embryos, } \mathrm{mm} \\
\text { Ukuran embrio somatic, } \mathrm{mm}\end{array}$} \\
\hline & $\begin{array}{l}\text { Initiation stage } \\
\text { Tahap inisiasi }\end{array}$ & $\begin{array}{l}\text { Reproduction stage } \\
\text { Tahap reproduksi }\end{array}$ & $\begin{array}{l}\text { Initiation stage } \\
\text { Tahap inisiasi }\end{array}$ & $\begin{array}{l}\text { Reproduction stage } \\
\text { Tahap reproduksi }\end{array}$ \\
\hline $\mathrm{N}$ & $29 a$ & $48 \mathrm{a}$ & $2.6 \mathrm{a}$ & $2.6 \mathrm{a}$ \\
\hline T-1 & $29 a$ & $47 \mathrm{a}$ & $2.8 \mathrm{a}$ & $2.9 \mathrm{a}$ \\
\hline $\mathrm{T}-2$ & $30 \mathrm{a}$ & $47 \mathrm{a}$ & $2.9 \mathrm{a}$ & $3.1 \mathrm{a}$ \\
\hline $\mathrm{T}-3$ & $31 \mathrm{a}$ & $49 a$ & $2.7 \mathrm{a}$ & $2.8 \mathrm{a}$ \\
\hline $\mathrm{T}-4$ & $29 \mathrm{a}$ & $52 \mathrm{a}$ & $2.7 \mathrm{a}$ & $2.8 \mathrm{a}$ \\
\hline $\mathrm{T}-5$ & $28 \mathrm{a}$ & $49 a$ & $2.7 \mathrm{a}$ & $2.9 \mathrm{a}$ \\
\hline T-6 & $29 a$ & $48 \mathrm{a}$ & $2.6 \mathrm{a}$ & $2.9 \mathrm{a}$ \\
\hline $\mathrm{T}-7$ & $30 \mathrm{a}$ & $48 \mathrm{a}$ & $2.8 \mathrm{a}$ & $2.8 \mathrm{a}$ \\
\hline T-8 & $32 \mathrm{a}$ & $48 \mathrm{a}$ & $2.8 \mathrm{a}$ & $2.8 \mathrm{a}$ \\
\hline T-9 & $30 \mathrm{a}$ & $50 \mathrm{a}$ & $2.9 \mathrm{a}$ & $3.2 \mathrm{a}$ \\
\hline $\mathrm{T}-10$ & $32 \mathrm{a}$ & $49 \mathrm{a}$ & $2.9 \mathrm{a}$ & $3.2 \mathrm{a}$ \\
\hline
\end{tabular}

Notes (Catatan): Numbers in the same column followed by the same letter are not significantly different according to $\mathrm{T}$ test $5 \%$. Notations code of plant accession refers to Table 1. (Angka-angka dalam kolom yang sama jika diikuti oleh huruf yang sama tidak berbeda nyata menurut uji T taraf 5\%. Notasi aksesi tanaman mengacu pada Tabel 1). 


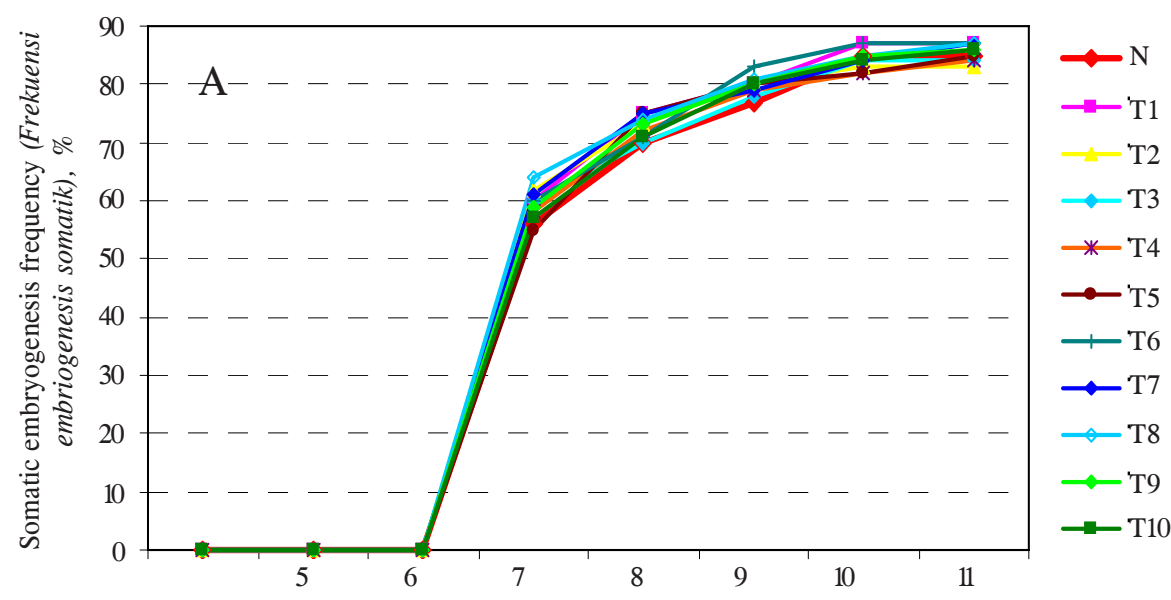

Culture length, weeks (Masa kultur, minggu)

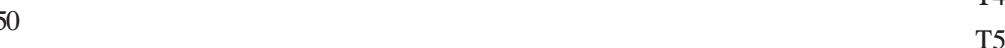

Figure 3. Precocity and frequency of soma of transgenic plant of Robusta co plant accession number of 1-10 stage of somatic embryo.

Gambar 3. Kecepatan dan frekuensi embriog kopi Robusta transgenik. Catata

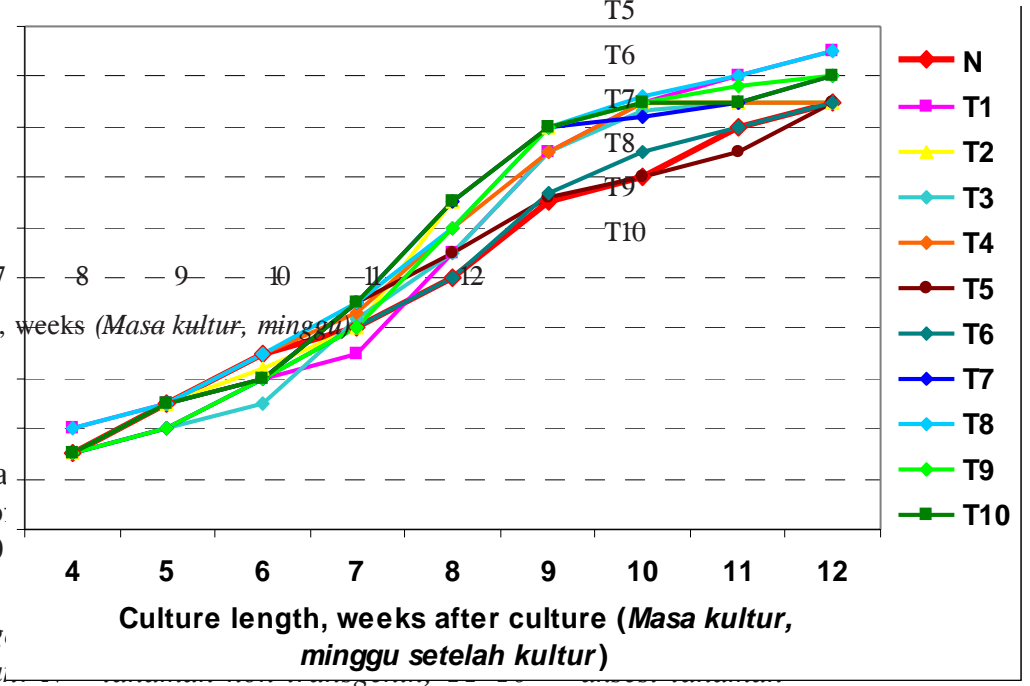
transgenik nomor 1-10. A. Tahap induksi embrio somatik, B. Tahap reproduksi embrio somatik. 
Table 3. Somatic embryo development on somatic embryo initiation and reproduction stage of in vitro culture of transgenic plants of Robusta coffee

Tabel 3. Perkembangan embrio somatik pada tahap inisiasi dan reproduksi embrio somatik beberapa aksesi tanaman transgenik kopi Robusta

\begin{tabular}{|c|c|c|c|c|c|c|}
\hline \multirow{2}{*}{$\begin{array}{l}\text { Plant } \\
\text { accession } \\
\text { Aksesi } \\
\text { tanaman }\end{array}$} & \multicolumn{2}{|c|}{$\begin{array}{l}\text { Pre-embryoid phase, } \% \\
\text { Fase pra embrioid, } \%\end{array}$} & \multicolumn{2}{|c|}{$\begin{array}{l}\text { Cotyledonary phase, } \% \\
\text { Fase kotiledon, } \%\end{array}$} & \multicolumn{2}{|c|}{$\begin{array}{l}\text { Pre-germinated phase, } \% \\
\text { Fase pra kecambah, } \%\end{array}$} \\
\hline & $\begin{array}{l}\text { Initiation } \\
\text { stage } \\
\text { Tahap } \\
\text { inisiasi } \\
\end{array}$ & $\begin{array}{c}\text { Reproduction } \\
\text { stage } \\
\text { Tahap } \\
\text { reproduksi }\end{array}$ & $\begin{array}{c}\text { Initiation } \\
\text { stage } \\
\text { Tahap } \\
\text { inisiasi }\end{array}$ & $\begin{array}{c}\text { Reproduction } \\
\text { stage } \\
\text { Tahap } \\
\text { reproduksi }\end{array}$ & $\begin{array}{c}\text { Initiation } \\
\text { stage } \\
\text { Tahap } \\
\text { inisiasi } \\
\end{array}$ & $\begin{array}{c}\text { Reproduction } \\
\text { stage } \\
\text { Tahap } \\
\text { reproduksi }\end{array}$ \\
\hline $\mathrm{N}$ & $51 \mathrm{a}$ & $29 a$ & $37 \mathrm{a}$ & $53 \mathrm{a}$ & $12 \mathrm{a}$ & $18 \mathrm{a}$ \\
\hline $\mathrm{T}-1$ & $54 \mathrm{a}$ & $27 \mathrm{a}$ & $34 \mathrm{a}$ & $55 \mathrm{a}$ & $12 \mathrm{a}$ & $18 \mathrm{a}$ \\
\hline $\mathrm{T}-2$ & $54 \mathrm{a}$ & $30 \mathrm{a}$ & $33 \mathrm{a}$ & $55 \mathrm{a}$ & $13 \mathrm{a}$ & $15 \mathrm{a}$ \\
\hline $\mathrm{T}-3$ & $53 \mathrm{a}$ & $25 \mathrm{a}$ & $33 \mathrm{a}$ & $56 \mathrm{a}$ & $14 \mathrm{a}$ & $19 \mathrm{a}$ \\
\hline $\mathrm{T}-4$ & $58 \mathrm{a}$ & $27 \mathrm{a}$ & $32 \mathrm{a}$ & $57 a$ & $10 \mathrm{a}$ & $16 \mathrm{a}$ \\
\hline T-5 & $59 a$ & $28 \mathrm{a}$ & $29 a$ & $54 \mathrm{a}$ & $12 \mathrm{a}$ & $18 \mathrm{a}$ \\
\hline T-6 & $52 \mathrm{a}$ & $26 \mathrm{a}$ & $37 a$ & $56 \mathrm{a}$ & $11 \mathrm{a}$ & $18 \mathrm{a}$ \\
\hline T-7 & $55 \mathrm{a}$ & $26 \mathrm{a}$ & $34 \mathrm{a}$ & $55 \mathrm{a}$ & $11 \mathrm{a}$ & $19 a$ \\
\hline T-8 & $53 \mathrm{a}$ & $28 \mathrm{a}$ & $34 \mathrm{a}$ & $56 \mathrm{a}$ & $13 \mathrm{a}$ & $16 \mathrm{a}$ \\
\hline T-9 & $55 \mathrm{a}$ & $26 \mathrm{a}$ & $33 \mathrm{a}$ & $55 \mathrm{a}$ & $12 \mathrm{a}$ & $19 a$ \\
\hline $\mathrm{T}-10$ & $58 \mathrm{a}$ & $25 \mathrm{a}$ & $32 \mathrm{a}$ & $57 \mathrm{a}$ & $10 \mathrm{a}$ & $18 \mathrm{a}$ \\
\hline
\end{tabular}

Notes (Catatan): Numbers in the same column when followed by the same letter are not significantly different according to $\mathrm{T}$ test 5\%. Notations code of plant accession refers to Table 1. (Angka-angka dalam kolom yang sama jika diikuti oleh huruf yang sama tidak berbeda nyata menurut uji T taraf $5 \%$. Notasi aksesi tanaman mengacu pada Tabel 1).

was necessary to have a system of genic transference that was simple, cheap, reproducible and independent of the genotype.

\section{Maturation of somatic embryo}

The maturation of somatic embryos was significantly affected by kinds of fresh liquid culture medium added on ancient gelled medium contained somatic embryos of reproduction stage. However it was not significantly affected by plant accession on all observed parameters (Table 5). In these studies, the number and size of somatic embryos of transgenic plant were still similar both with non-transgenic and among transgenic one. Furthermore, the increased size of somatic embryos was the greatest when 8 weeks old culture of somatic embryos reproduction stage added by fresh liquid medium enriched by $0.25 \mathrm{mg} / l \mathrm{GA}_{3}$ as compared with addition of fresh liquid medium enriched by $0.15 \mathrm{mg} / l$ IAA and by 0.25 $\mathrm{mg} / \mathrm{l}$ Kinetin as well as the long cultured on the ancient medium. The different result was showed that the increased number of somatic embryos was greatest when 8 weeks old culture of somatic embryos reproduction stage added by fresh liquid medium enriched by $0.15 \mathrm{mg} / l \mathrm{IAA}$. Somatic embryos maintained on the medium enriched with $0.25 \mathrm{mg} / \mathrm{l}$ kinetin tend to sprouted. These result showed that $\mathrm{GA}_{3}$ convenient for 
Table 4. Germination of somatic embryos of transgenic plant of Robusta coffee on medium contained of different concentration of sucrose

Tabel 4. Pengecambahan embrio somatik tanaman transgenik kopi Robusta pada media yang mengandung berbagai konsentrasi sukrosa

\begin{tabular}{lcccccc}
\hline Treatments & Germinated & Fresh weight of & Dry matter of & Number of root & Root length & Shoot high \\
Perlakuan & embryos & plantlet & plantlet & per plantlet & Panjang & Tinggi \\
& Embrio & Berat segar & Berat kering & Jumlah akar per & akar, mm & plantlet, mm \\
& berkecambah, $\%$ & plantlet, mg & plantlet, $\%$ & plantlet & & \\
\hline
\end{tabular}

Sucrose concentration

Konsentrasi sukrosa, \%

\begin{tabular}{|c|c|c|c|c|c|c|}
\hline 20 & $75 \mathrm{a}$ & $58 \mathrm{a}$ & $21 \mathrm{a}$ & $1.8 \mathrm{a}$ & $7 a$ & $10 \mathrm{a}$ \\
\hline 30 & $87 a b$ & $65 \mathrm{a}$ & $22 \mathrm{a}$ & $2.1 \mathrm{a}$ & $8 \mathrm{a}$ & $16 \mathrm{ab}$ \\
\hline 40 & $95 \mathrm{~b}$ & $130 \mathrm{~b}$ & $32 \mathrm{~b}$ & $3.5 \mathrm{~b}$ & $11 \mathrm{~b}$ & $23 \mathrm{~b}$ \\
\hline
\end{tabular}

Plant accession (Aksesi tanaman)

\begin{tabular}{|c|c|c|c|c|c|c|}
\hline $\mathrm{N}$ & $90 \mathrm{a}$ & $71 \mathrm{a}$ & $25 \mathrm{a}$ & $2.9 \mathrm{a}$ & $8 \mathrm{a}$ & $18 \mathrm{a}$ \\
\hline T-1 & $91 \mathrm{a}$ & $69 a$ & $27 \mathrm{a}$ & $2.9 \mathrm{a}$ & $9 \mathrm{a}$ & $17 \mathrm{a}$ \\
\hline $\mathrm{T}-2$ & $90 \mathrm{a}$ & $72 \mathrm{a}$ & $26 \mathrm{a}$ & $3.1 \mathrm{a}$ & $8 \mathrm{a}$ & $16 \mathrm{a}$ \\
\hline T-3 & $88 \mathrm{a}$ & $69 \mathrm{a}$ & $24 \mathrm{a}$ & $3.0 \mathrm{a}$ & $8 \mathrm{a}$ & $20 a$ \\
\hline $\mathrm{T}-4$ & $89 a$ & $70 \mathrm{a}$ & $23 \mathrm{a}$ & $3.2 \mathrm{a}$ & $9 \mathrm{a}$ & $21 \mathrm{a}$ \\
\hline T-5 & $91 \mathrm{a}$ & $70 \mathrm{a}$ & $26 \mathrm{a}$ & $3.0 \mathrm{a}$ & $8 \mathrm{a}$ & $18 \mathrm{a}$ \\
\hline T-6 & $92 \mathrm{a}$ & $73 \mathrm{a}$ & $25 \mathrm{a}$ & $2.9 \mathrm{a}$ & $8 \mathrm{a}$ & $17 \mathrm{a}$ \\
\hline T-7 & $89 a$ & $72 \mathrm{a}$ & $27 \mathrm{a}$ & $2.9 \mathrm{a}$ & $9 \mathrm{a}$ & $19 a$ \\
\hline T-8 & $92 \mathrm{a}$ & $70 \mathrm{a}$ & $27 \mathrm{a}$ & $3.1 \mathrm{a}$ & $8 \mathrm{a}$ & $18 \mathrm{a}$ \\
\hline T-9 & $92 \mathrm{a}$ & $70 \mathrm{a}$ & $25 \mathrm{a}$ & $3.1 \mathrm{a}$ & $8 \mathrm{a}$ & $18 \mathrm{a}$ \\
\hline $\mathrm{T}-10$ & $90 \mathrm{a}$ & $72 \mathrm{a}$ & $26 \mathrm{a}$ & $3.2 \mathrm{a}$ & $8 \mathrm{a}$ & $19 a$ \\
\hline
\end{tabular}

Notes (Catatan): Numbers in the same column when followed by the same letter are not significantly different according to T test 5\%. Notations of code of plant accession refers to Table 1. (Angka-angka dalam kolom yang sama jika diikuti oleh huruf yang sama tidak berbeda nyata menurut uji T taraf $5 \%$. Notasi aksesi tanaman mengacu pada Tabel 1).

cell elongation, IAA for cell proliferation, and kinetin for cell differentiation on in vitro culture both of transgenic plant and nontransgenic one of Robusta coffee. In contrary, the survival number of somatic embryos was declined when 8 weeks old culture of somatic embryos reproduction was maintained for long term on the ancient medium. These results was similar with Han et al. (2000), which showed that the loss of regeneration capacity occurred in Asiatic hybrid lily after 60 weeks culture.
The percentage of pre-germinated of all plant accession was not significantly different (Table 5). It means that somatic embryos development of transgenic plant was similar with both non-transgenic and among transgenic one. These results showed that somatic embryos maturation was independent to plant accession, whereas there was no difference between somatic embryos derived from both all transgenic plant accession and all non-transgenic plant accession. The others results showed that the somatic 
embryos development could be improved by addition of fresh liquid medium on the ancient medium of somatic embryos reproduction stage. The percentage of pre-embryoid somatic embryos phase was reduced by addition of fresh liquid medium enriched both by $0.15 \mathrm{mg} / l \mathrm{IAA}$ and $0.25 \mathrm{mg} / l \mathrm{GA}_{3}$. In the other hand the percentage of pre-germinated somatic embryos was increased by addition of fresh liquid medium enriched both by $0.15 \mathrm{mg} / l \mathrm{IAA}$ and $0.25 \mathrm{mg} / \mathrm{l} \mathrm{GA}$. Addition of fresh liquid medium enriched by $0.25 \mathrm{mg} / \mathrm{GA}_{3}$ give both the lowest percentage of pre-embryoid somatic embryos phase and the highest percentage of pre-germinated somatic embryos phase. Furthermore long culture of somatic embryos reproduction on the ancient medium was not able to support the growth of somatic embryos. The similar result was reported by Priyono (2005) on in vitro culture vanilla, whereas the development of protocorm-like body to shoot sprout was stimulated by addition $0.25-1.0 \mathrm{mg} / l$ both $\mathrm{GA}_{3}$ and IAA.

Table 5. Number, size, and phase of somatic embryo on somatic embryo maturation medium of in vitro culture of several transgenic plant of Robusta coffee

Tabel 5. Jumlah, ukuran, dan fase perkembangan embrio somatik pada tahap pendewasaan embrio somatik asal tanaman transgenik kopi Robusta

\begin{tabular}{|c|c|c|c|c|c|}
\hline \multirow{2}{*}{$\begin{array}{l}\text { Treatments } \\
\text { Perlakuan }\end{array}$} & \multicolumn{2}{|c|}{$\begin{array}{l}\text { Somatic embryo } \\
\text { Embrio somatik }\end{array}$} & \multicolumn{3}{|c|}{$\begin{array}{l}\text { Somatic embryo development, } \% \\
\text { Perkembangan embrio somatik, \% }\end{array}$} \\
\hline & $\begin{array}{l}\text { Number } \\
\text { Jumlah }\end{array}$ & $\begin{array}{l}\text { Size, mm } \\
\text { Ukuran, mm }\end{array}$ & $\begin{array}{l}\text { Preembryoid } \\
\text { Pra embrioid }\end{array}$ & $\begin{array}{l}\text { Cotyledonary } \\
\text { Kotiledon }\end{array}$ & $\begin{array}{l}\text { Pregerminated } \\
\text { Pra kecambah }\end{array}$ \\
\hline \multicolumn{6}{|l|}{ Medium } \\
\hline M1 & $39 \mathrm{a}$ & $3.0 \mathrm{a}$ & $40 \mathrm{c}$ & $38 \mathrm{ab}$ & $22 \mathrm{a}$ \\
\hline M2 & $54 \mathrm{~b}$ & $3.3 \mathrm{a}$ & $35 \mathrm{bc}$ & $48 \mathrm{~b}$ & $17 \mathrm{a}$ \\
\hline M3 & $52 \mathrm{~b}$ & $4.5 \mathrm{~b}$ & $27 \mathrm{~b}$ & $49 \mathrm{~b}$ & $24 \mathrm{a}$ \\
\hline M4 & $53 \mathrm{~b}$ & $4.8 \mathrm{~b}$ & $10 \mathrm{a}$ & $25 \mathrm{a}$ & $65 \mathrm{~b}$ \\
\hline \multicolumn{6}{|c|}{ Plant accession (Aksesi tanaman) } \\
\hline $\mathrm{N}$ & $50 \mathrm{a}$ & $3.7 \mathrm{a}$ & $20 \mathrm{a}$ & $35 \mathrm{a}$ & $45 \mathrm{a}$ \\
\hline $\mathrm{T}-1$ & $51 \mathrm{a}$ & $3.8 \mathrm{a}$ & $22 \mathrm{a}$ & $32 \mathrm{a}$ & $46 \mathrm{a}$ \\
\hline $\mathrm{T}-2$ & $50 \mathrm{a}$ & $3.9 \mathrm{a}$ & $21 \mathrm{a}$ & $33 \mathrm{a}$ & $46 \mathrm{a}$ \\
\hline $\mathrm{T}-3$ & $53 \mathrm{a}$ & $4.2 \mathrm{a}$ & $23 \mathrm{a}$ & $30 \mathrm{a}$ & $47 \mathrm{a}$ \\
\hline $\mathrm{T}-4$ & $56 \mathrm{a}$ & $3.7 \mathrm{a}$ & $23 \mathrm{a}$ & $30 \mathrm{a}$ & $47 \mathrm{a}$ \\
\hline $\mathrm{T}-5$ & $55 \mathrm{a}$ & $4.0 \mathrm{a}$ & $22 \mathrm{a}$ & $30 \mathrm{a}$ & $48 \mathrm{a}$ \\
\hline T-6 & $56 \mathrm{a}$ & $3.8 \mathrm{a}$ & $24 \mathrm{a}$ & $32 \mathrm{a}$ & $44 \mathrm{a}$ \\
\hline T-7 & $54 \mathrm{a}$ & $3.9 \mathrm{a}$ & $24 \mathrm{a}$ & $32 \mathrm{a}$ & $44 \mathrm{a}$ \\
\hline T-8 & $54 \mathrm{a}$ & $3.9 \mathrm{a}$ & $22 \mathrm{a}$ & $30 \mathrm{a}$ & $48 \mathrm{a}$ \\
\hline T-9 & $55 \mathrm{a}$ & $4.1 \mathrm{a}$ & $23 \mathrm{a}$ & $34 \mathrm{a}$ & $43 \mathrm{a}$ \\
\hline T-10 & $55 \mathrm{a}$ & $4.0 \mathrm{a}$ & $22 \mathrm{a}$ & $30 \mathrm{a}$ & $48 \mathrm{a}$ \\
\hline
\end{tabular}

Notes (Catatan): Numbers in the same column when followed by the same letter are not significantly different according to $\mathrm{T}$ test 5\%. Notations code of M1-M4 reefers to Figure 4 and notations code of plant accession refers to Table 1. (Angka-angka dalam kolom yang sama jika diikuti oleh huruf yang sama tidak berbeda nyata menurut uji T taraf 5\%. Notasi M1-M4 mengacu pada Gambar 4 dan notasi aksesi tanaman mengacu pada Tabel 1). 

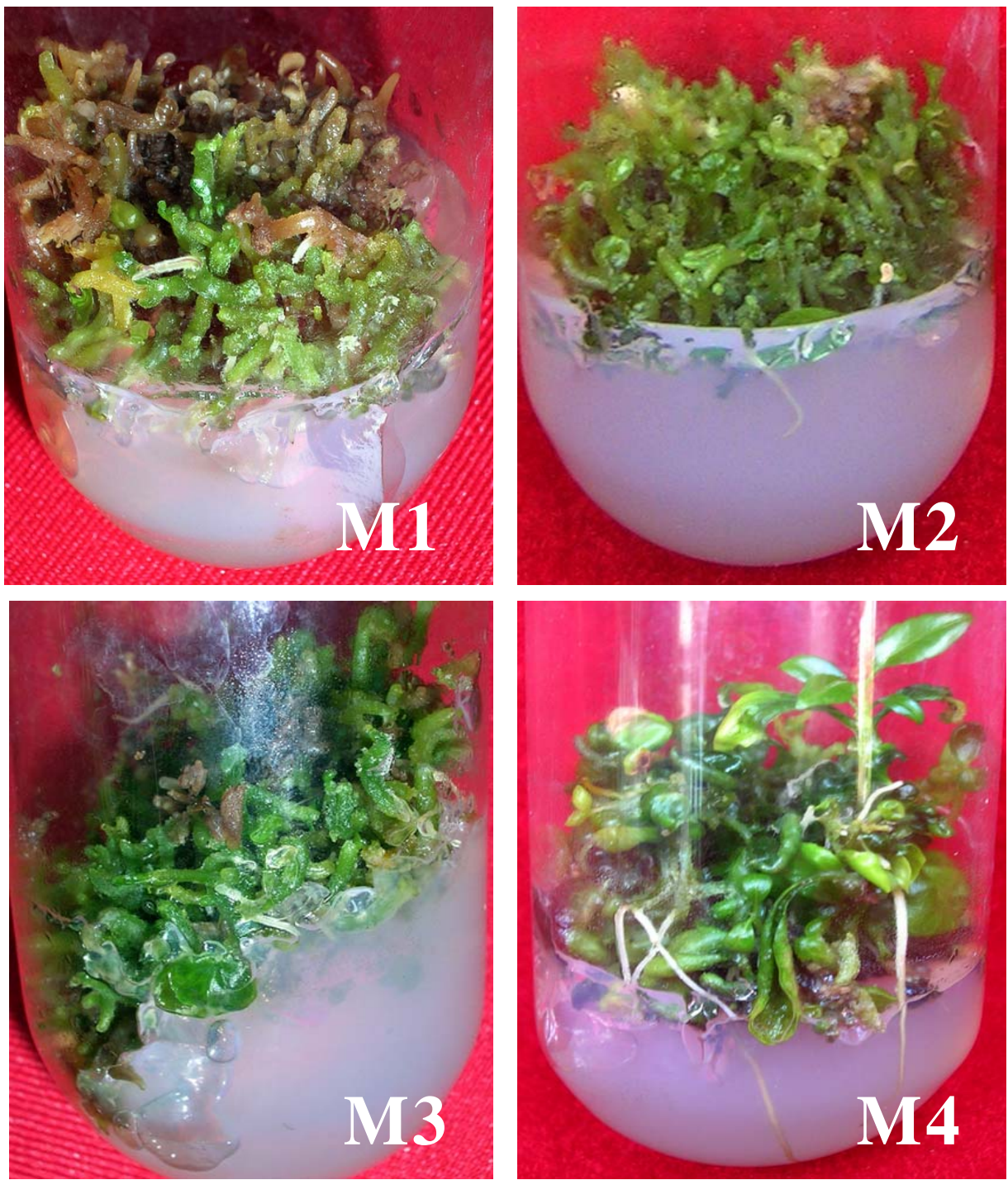

Figure 4. Somatic embryos maturation of transgenic Robusta coffee. M1: ancient gelled somatic embryo reproduction medium without addition of liquid medium, M2: ancient gelled somatic embryo reproduction medium added by liquid medium contained $0.25 \mathrm{mg} / \mathrm{l}$ kinetin, $\mathrm{M} 3$ : ancient gelled somatic embryo reproduction medium added by liquid medium contained $0.25 \mathrm{mg} / \mathrm{l}$ IAA and M4: ancient gelled somatic embryo reproduction medium added by liquid medium contained $0.25 \mathrm{mg} / 1 \mathrm{GA}_{3}$.

Gambar 4. Pendewasaan embrio somatik tanaman transgenik kopi Robusta. Catatan: M1: media reproduksi embrio somatik padat tanpa ditambah media cair, M2: media reproduksi embrio somatik padat ditambah media cair mengandung 0,25 mg/l kinetin, M3: media reproduksi embrio somatik padat ditambah media cair mengandung 0,25 $\mathrm{mg} / \mathrm{l}$ IAA and M4: media reproduksi

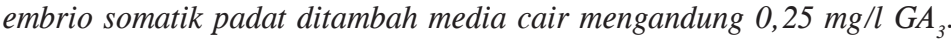


Kinetin could not stimulate its development, which the best result of protocorm-like body development rate, namely $90 \%$ was obtained from medium contained $0.25 \mathrm{mg} / l \mathrm{GA}_{3}$.

One of serious problems facing micropropagation industry was many losses occur mostly due to heterogeneity and relatively poor development of the somatic embryos during reproduction stages. In the last decade, several reports indicate that under the proper control of culture could improve the somatic embryo performance. Kozai et al. (1986) proved that the gaseous environment in the culture vessel could greatly affect the growth of an in vitro plantlet. Furthermore, Infante et al. (1989) showed that in vitro plantlet grew well on the sugar-free medium; especially under high photosynthetic photon flux and $\mathrm{CO}_{2}$ enriched condition. Nguyen et al. (1999) reported that the growth of somatic embryos of in vitro coffee when cultured on Florialite soaked in sugar-free medium and under the higher number of air exchanges were better than those in sugar containing medium. The improvement of somatic embryos growth could be done by temporary liquid immersion (Tahardi et al., 2000). EtienneBerry et al. (1999) have succeeded for mass production of somatic embryos of Arabica coffee in good homogeneity and well development when using the bioreactor.

\section{CONCLUSIONS}

1. By using DNA marker test concluded that 8 out of 10 accessions of BP 308 clone of Robusta coffee produced by direct somatic embryogenesis from pre-embryonic of somatic embryos after transformed by chitinase gene mediated by Agrobacterium tumefaciens LBA4404 strain carrying pCAMBIA2301-chi were transgenic plants.

2. Somatic embryogenesis abilities of all accession of transgenic plant were similar with non-transgenic one.

3. Germination of somatic embryos was improved by enriching of $40 \%$ sucrose.

4. Maturation of somatic embryo could be obtained by addition of fresh liquid medium contained $0.25 \mathrm{mg} / l \mathrm{GA}_{3}$ on ancient gelled medium whereas the somatic embryos cluster growth.

\section{REFERENCES}

Barton, C.R.; T.L. Adams \& M.A. Zarowitz (1991). Stable transformation of foreign DNA into Coffea arabica plants. p. 460-464. In: Proceedings of $14^{\text {th }} \mathrm{Col}$ loquium of International Coffee Science Association (ASIC), San Francisco, USA.

Broglie K.; I. Chet; M. Holliday; R. Cressman; P. Biddle; S. Knowlton; C.J. Mauvanis \& R. Broglie (1991). Transgenic plants with enhanced resistance to fungal pathogen Rizoctonia solani. Science, 254, 1194-1197.

Budiani, A.; Priyono; Siswanto; T. Chaidamsari \& S. Mawardi (2000). Transformation of Coffea arabica using chitinase gene and regeneration of plantlets from transformed-zigotic embryos. Menara Perkebunan, 68, 1-11.

Da Silva, F. \& M. Yuffa (2003). Transient gene expresion in secondary somatic embryos from coffee tisúes electro-porated with the genes gus and bar. Plant Biotechnology, 6, 1-6. 
Etienne-Berry, D.; B. Bertrand; N. Vasquez \& H. Etienne (1999). Direct sowing of Coffea arabica somatic embryos mass produced in a bioreactor and regeneration of plants. Plant Cell Reports, 19, 111-117.

Han, D.S.; Y. Niimi \& M. Nakano (2000). Long term maintenance of an antherderived haploid callus line of the Asiatic hybrid lily Connecticut King. Plant Cell, Tissue and Organ Culture, 61, 215-219.

Hatanaka, T.; O. Arakawa; T. Yasuda; N. Uchida \& T. Yamaguchi (1991). Effect of plant growth regulators on somatic embryogenesis in leaf cultures of Coffea canephora. Plant Cell Reports, 10, 179182.

Infante, R.; E. Magnanini \& B. Righetti (1989). The role of light and $\mathrm{CO}_{2}$ on optimizing the conditions of shoot proliferation of Actinidia delisiosa in vitro. Physio. Plant, 77, 191-195.

Kozai, T.; K. Fujiwara \& I. Watanabe (1986). Fundamentals studies of environments in plant tissue culture vessels. (2) Effect of stoppers and vessels on gas exchange rates between inside and outside of vessels closed with stoppers. J. Agr. Meteorol., 42, 119-127.

Leroy, T.; A.M. Henry; M. Royer; I. Altosaar; R. Frutos; D. Duris \& R. Philippe (2000). Genetically modified coffee plants expressing the Bacillus thuringiensis cry 1 Ac gene for resistance to leaf miner. Plant Cell Reports, 19, 382-389.

Lin, W.; C.S. Anuratha; K. Datta; I. Potrykus, Mathukrisnan \& S.K. Datta (1995). Genetic engineering of rice for resistance to sheath blight. Biotechnology, 13, 686-691.
Nguyen, Q.T.; T. Kozai; U.V. Nguyen (1999). Effect of sucrose concentration, supporting material and number of air exchange of the vessel on the growth of in vitro coffee plantlets. Plant Cell, Tissue and Organ Culture, 58, 51-57.

Priyono; Matsaleh; D. Suhendi (2000). Daya regenerasi dan morfisme pertumbuhan bibit hasil kultur jaringan daun ortotrop dan plagiotrop Coffea canephora melalui embryogenesis somatik. Pelita Perkebunan, 16, 65-74.

Priyono; S. Mawardi; T. Chaidamsari; A. Budiani \& Siswanto (2001). Regenerasi kopi Robusta secara in vitro berbagai eksplan pasca transformasi gen kitinase melalui Agrobacterium tumefacien. Pelita Perkebunan, 17, 85-96.

Priyono (2004). Kultur in vitro daun kopi untuk mengetahui kemampuan embriogenesis somatik berbagai spesies kopi. Pelita Perkebunan, 20, 1-14.

Priyono (2005). Vanila (Vanilla planifolia Andrew) micropropagation through protocorm-like body formation on in vitro culture of node slice. Agrivita, $27,86-95$.

Raharjo S.H.T.; M.O. Hernandez; Y.Y. Zhang \& Z.K. Punja (1996). Transformation of Pikling Cucumber with Chitinaseencoding Genes using Agrobacterium tumefaciens. Plant Cell Rep., 15, 591 -596 .

Roberts, A.V.; E.F. Smith; I. Horan; S. Walker; D. Matthews \& J. Mottley (1994). Stage III techniques for improving water relations and autotrophy in micropropagated plants. p.314-322. In : Lumsden, P.J., J.R. Nicholas \& W.J. Davies (Eds.) Physiology, Growth and Development of Plants in Culture. Kluer academic Publishers. Dordrecht, The Netherlands. 
Spiral, J.; C. Thierrey; M. Paillard; V. Petiard (1993). Obtention de plantules de Coffea canephora Pierre transformées par Agrobacterium rhizogenes. Comptes Rendus d'Academie des Science Paris.

Siswanto; F. Oktavia; A. Budiani; Sudarsono, Priyono \& S. Mawardi (2003). Transformasi kopi Robusta (Coffea canephora) dengan gen kitinase melalui Agrobacterium tumefaciens LBA4404. Menara Perkebunan, 71, 56-69.

Tahardi, J.S.; T. Raisawati; I. Riyadi \& W.A. Dodd (2000). Direct somatic embryogenesis and plant regeneration in tea by temporary liquid immersion. Menara Perkebunan, 68, 1-9.

Takazama, A. \& T. Kozai (1992). Effect of types of culture vessels with supporting materials on the growth of carnation plantlets in vitro. Control Biol., 30, 65-70.

Terakawa, T.; N. Takaya; H. Horiuchi \& M. Koike (1997). A fungal chitinase gene from Rhizopus oligosporus confer antifungal activity to transgenic tobacco. Plant Cell Rep., 16, 439-443.
Van Boxtel, J.; M. Berthouly; C. Carasco; M. Dufour \& A. Eskes (1995). Transient expression of $\beta$-glucuronidase following biolistic delivery of foreign DNA into coffee tissues. Plant Cell Rep., 14, 748-752.

Wirawan, I.G.P.; S. Subandiyah; W. N. Suprapta; N. Arya; P. Supartana \& M. Sudana. (1999). Organogenic regeneration of transgenic plant by Agrobacterium-mediated DNA transformation of citrus. Procc. Inter. Seminar on Plant Mol. Biol., Jember, 31-36.

Zamarripa, A.; J.P. Ducos; H. Bollon; M. Dufour \& V. Petiard (1991). Production d'embryons somatiques de cafe eier en milieu liquode: effects densité d'inoculation et renouvellement du milieu. Cafe Cacao The, 25, 233-244. 